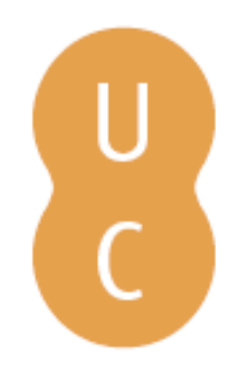

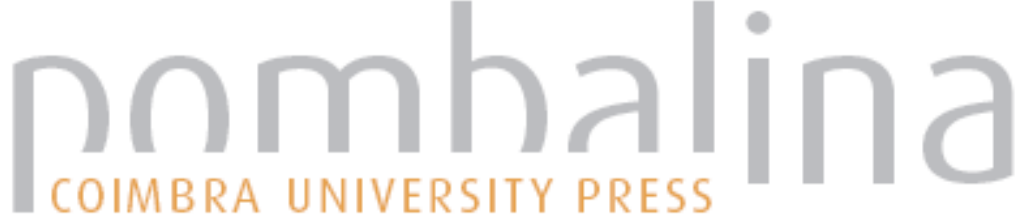

\section{Cartilhas Partilhadas: Notas sobre o I Curso de Especialização em Estudos Clássicos da UnB}

\author{
Autor(es): $\quad$ Pires, Antônio Donizeti \\ Publicado por: Imprensa da Universidade de Coimbra \\ URL \\ persistente: URI:http://hdl.handle.net/10316.2/44304 \\ DOI: $\quad$ DOI:https://doi.org/10.14195/978-989-26-1585-1_26 \\ Accessed : $\quad$ 26-Apr-2023 12:58:41
}

A navegação consulta e descarregamento dos títulos inseridos nas Bibliotecas Digitais UC Digitalis, UC Pombalina e UC Impactum, pressupõem a aceitação plena e sem reservas dos Termos e Condições de Uso destas Bibliotecas Digitais, disponíveis em https://digitalis.uc.pt/pt-pt/termos.

Conforme exposto nos referidos Termos e Condições de Uso, o descarregamento de títulos de acesso restrito requer uma licença válida de autorização devendo o utilizador aceder ao(s) documento(s) a partir de um endereço de IP da instituição detentora da supramencionada licença.

Ao utilizador é apenas permitido o descarregamento para uso pessoal, pelo que o emprego do(s) título(s) descarregado(s) para outro fim, designadamente comercial, carece de autorização do respetivo autor ou editor da obra.

Na medida em que todas as obras da UC Digitalis se encontram protegidas pelo Código do Direito de Autor e Direitos Conexos e demais legislação aplicável, toda a cópia, parcial ou total, deste documento, nos casos em que é legalmente admitida, deverá conter ou fazer-se acompanhar por este aviso.

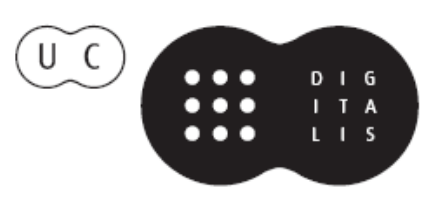




\section{COLEÇÃO FILOSOFIA E TRA DIÇÃO}

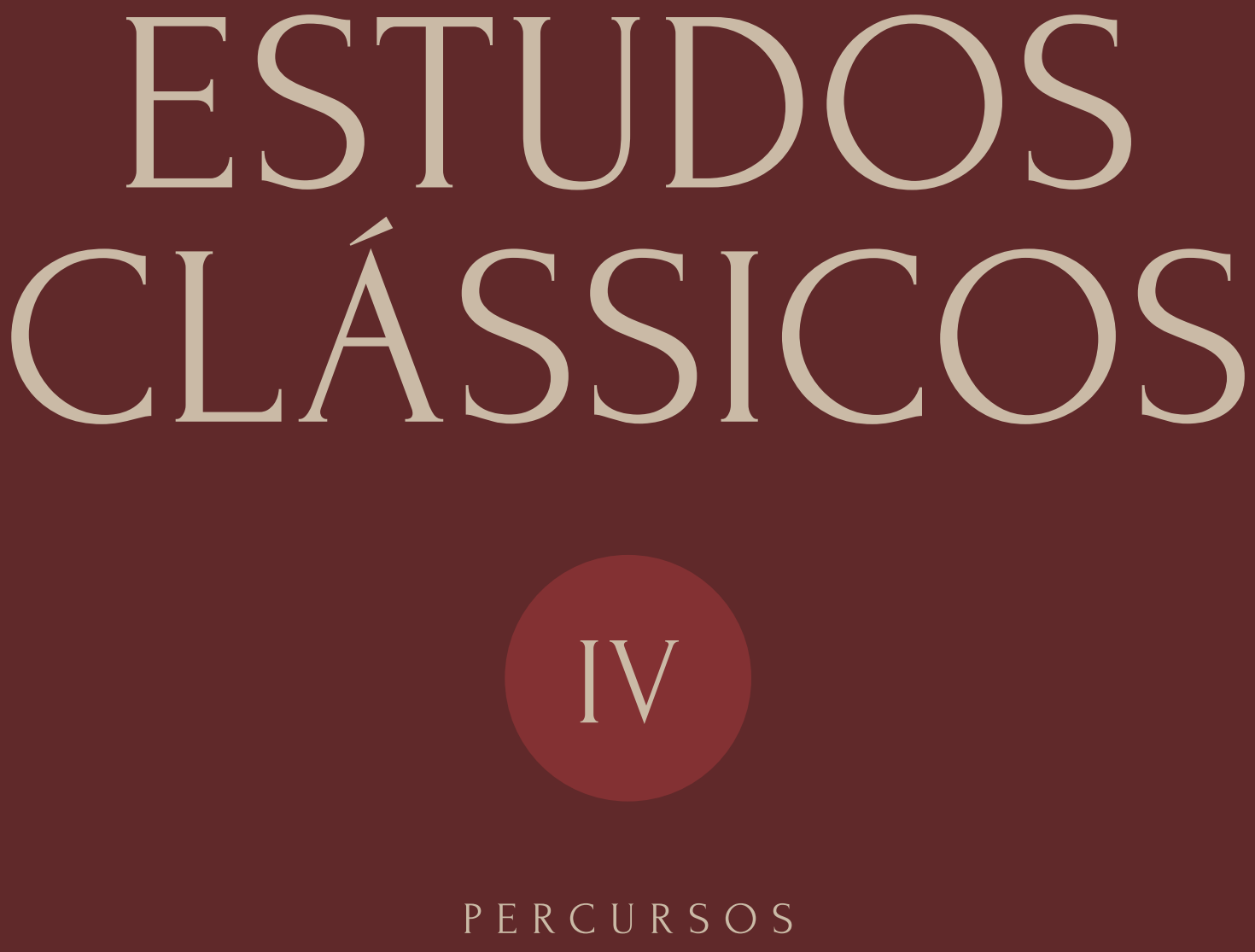

Gabriele Cornelli
Luciano Coutinho 


\section{Cartilhas Partilhadas: Notas sobre o I Curso de Especialização em Es- tudos Clássicos da UnB}

Antônio Donizeti Pires ${ }^{378}$

Para mim, foi motivo de honra e orgulho ter participado, como aluno, da primeira turma do I Curso de Especialização em Estudos Clássicos da UnB, embora eu tivesse, naquele momento, defendido o Doutorado há pelo menos 10 anos (agosto de 2002). O fato inusitado pode parecer estranho, mas teve importância considerável na minha trajetória humanística porque me proporcionou agregar, à formação que tive em Estudos Literários (literatura comparada; história, teorias e crítica da poesia lírica, do drama e da narrativa), uma oportuna sistematização de conhecimentos sobre a Antiguidade greco-latina e uma melhor redefinição dos meus objetivos acadêmicos, uma vez que a pesquisa atual que desenvolvo versa sobre o mito de Orfeu (e do Orfismo) na poesia brasileira moderno-contemporânea.

Assim, nos corredores da UNESP/Araraquara (onde sou professor na área de Literatura Brasileira), tão logo tive notícia da Especialização, não hesitei em procurar detalhes sobre a proposta inovadora do curso, sobre sua estrutura e sobre o sugestivo rol de 15 disciplinas que comporiam a primeira versão, todas elas de evidente caráter interdisciplinar (ou multidisciplinar, melhor dizendo), e a serem ministradas por professores de respeitáveis Universidades brasileiras e convidados da Universidade de Coimbra (Portugal).

O I Curso de Especialização em Estudos Clássicos, sob coordenação do incansável Prof. Dr. Gabriele Cornelli (UnB), foi uma parceria 378 Prof. Dr. da Universidade Estadual de São Paulo - UNESP/Araraquara. Doutor (2002) pelo Programa de Pós-Graduação em Estudos Literários da FCL - UNESP/Araraquara, onde é professor na área de Literatura Brasileira desde 2004, atuando na Graduação e na Pós-Graduação. Formado em Direito pela Faculdade de Direito de Franca (1984), atualmente faz estágio de Pós-Doutoramento junto ao PPGFIL da UnB (Universidade de Brasília), Cátedra Archai UNESCO, sob o tema "Orfeu entre os filósofos: estudo do mito e do orfismo no pensamento grego antigo". 
entre a Cátedra UNESCO Archai (ligada ao PPGFIL/Departamento de Filosofia) e o Núcleo de Estudos Clássicos (NEC/CEAM), da UnB, e efetivou-se entre abril de 2012 e agosto de 2013. Relendo o compromisso que foi postado no site da Especialização (http://www.estudosclassicos.org/) em 1/2/2012, por seu coordenador, constata-se que os objetivos do curso (entre estes, a preocupação de "mostrar novos olhares sobre a Antiguidade") foram plenamente alcançados:

Considerando o crescente interesse acadêmico pela compreensão dos estudos clássicos e da tradição ocidental em suas variadas formas e expressões, o presente curso de especialização se propõe a colocar o estudante a confronto com o mundo clássico e suas riquezas. A formação de novos pesquisadores na área de estudos clássicos e de estudos da Antiguidade contribuirá [contribuiu] para a consolidação de uma área que se compreende como necessariamente interdisciplinar.

Tal interdisciplinaridade (ou multidisciplinaridade) será enfatizada logo mais nestas breves páginas, pois no momento considero mais apropriado expor a estrutura e a dinâmica do curso, além de seus modos de interação e avaliação.

O I Curso de Especialização em Estudos Clássicos (e esta foi mais uma inovação interessante, ao valer-se da tecnologia para difundir a educação) foi inteiramente oferecido em EaD (Educação a Distância) e disponibilizou, durante todo o tempo de sua duração, vídeos-aula das várias disciplinas, filmes e vídeos diversos, textos e fóruns de discussão e comunicação on line, através da plataforma Moodle. Além da ajuda e da disponibilidade da coordenação, dos professores responsáveis e do corpo técnico, os mais de 100 alunos matriculados puderam contar, divididos em três grupos denominados Medusa, Ésteno e Euríale (as três Górgonas da mitologia grega), com o apoio inestimável dos três tutores virtuais, respectivamente Priscilla Gontijo, Luciano Coutinho e Walter Neto, que não mediram esforços para o esclarecimento de 
dúvidas, para a provocação salutar do debate, para a pronta correção de trabalhos e para a sugestão bibliográfica, garantindo sempre o bom andamento das atividades.

Pois, sendo contínua a avaliação dos alunos, a cada disciplina todos deviam participar dos três momentos em que as aulas virtuais eram divididas: a) Primeiro momento: provocação e diálogo: após a vídeo-aula da disciplina, havia o necessário debate no fórum de discussões; b) Segundo momento: estruturação da leitura: ou seja, de aprofundamento do tema da aula, seja através da leitura de textos preparados pelo professor responsável, seja através do acesso a textos complementares, filmes e/ou vídeos diversos, com a necessária tarefa escrita que enviávamos até à data estipulada pelo tutor; c) Terceiro momento: pluralidade de alternativas: através de bibliografia e material complementar, pressupunha o adensamento crítico e metodológico do segundo momento e, em contrapartida, esperava a resposta crítica do aluno, tanto nas discussões do fórum, quanto na formulação de textos de extensão variada. As disciplinas de um crédito compunham-se de três momentos; as de dois (maioria absoluta), compunham-se de seis momentos, isto é, repetia-se, depois de nova vídeo-aula, o processo aqui sumarizado.

Além da avaliação contínua na rotina das disciplinas, houve provas escritas semestrais, presenciais, e a elaboração/defesa de uma monografia final (chamada TF - Trabalho Final), a partir de tema escolhido pelo aluno. A defesa da monografia teve lugar durante o XIX Congresso da Sociedade Brasileira de Estudos Clássicos (SBEC) / I Simpósio Luso-Brasileiro de Estudos Clássicos, duplo evento acontecido em Brasília, na UnB, entre os dias 8 e 12 de julho de 2013. Coroamento natural do I Curso de Especialização em Estudos Clássicos, a qualidade do Congresso da SBEC (composto de conferências, mesas-redondas temáticas, comunicações, minicursos e outras atividades) permitiu um 
contato acadêmico bastante proveitoso aos alunos da Especialização, motivando-os, e ao mesmo tempo abrindo espaço para que defendessem seus trabalhos finais perante bancas compostas por congressistas de competência internacional. Aos que não puderam estar presentes ao evento, por motivos pessoais e outros, a coordenação disponibilizou data posterior para as últimas defesas, também em Brasília, a fim de que todos tivessem seus direitos assegurados. Quanto à monografia, registre-se que seu passo a passo foi definido entre novembro/ dezembro de 2012, no âmbito da disciplina "Metodologia da pesquisa em Estudos Clássicos": escolhido o tema e o orientador, cada aluno escreveu e apresentou, como requisito de avalição, o projeto a ser desenvolvido. O Trabalho Final resultante da pesquisa, em formato de artigo científico dissertativo, foi entregue em data previamente definida (01/06/2013) e, conforme afirmado acima, defendido perante uma banca composta por dois membros competentes na área dos Estudos Clássicos (orientador e convidado).

Ainda na qualidade de aluno, e sem perder a nota pessoal, retorno às 15 disciplinas de que se compôs o I Curso de Especialização em Estudos Clássicos da UnB, buscando ressaltar, nos seguintes comentários, o alto teor de inter e multidisciplinaridade de que se revestiu o pioneiro projeto, uma vez que este, sem esquecer os métodos e os caminhos de análise e compreensão, enfatizou (por meio de rica e atualizada bibliografia) a filosofia e o direito; a educação prática e a teórica, do corpo e da mente/espírito; a história e a geografia; a ética e a política; a literatura e as artes plásticas; o teatro e a arquitetura; a pólis e o périplo; a paz e a guerra; o trabalho e o lazer; o comércio, a indústria e outras atividades econômicas; a conquista e a expansão dos impérios; o multiculturalismo e as trocas culturais entre povos; o rico cotidiano miúdo e os tipos humanos esquecidos pela História oficial tradicional... Enfim, novas visões a partir de novos conceitos revisionistas, críticos e 
teóricos, que têm marcado não apenas os Estudos Clássicos, mas toda a grande área das Humanidades e das Artes e Letras:

1. "Introdução à EaD": a cargo da Profa. Dra. Nara Pimentel (UnB), a disciplina teve por objetivos iniciar os alunos, teórica e metodologicamente, nos problemas mais prementes da Educação a Distância. Sempre defendendo o correto e bom uso da tecnologia a serviço da Educação e do conhecimento seleto, denunciando projetos mirabolantes dos governos estaduais e federal, mas também elogiando as inciativas oportunas destes e de particulares, o curso foi fundamental para sanar as dúvidas e desconfianças que eu, particularmente, ainda mantinha em relação a essa útil e necessária modalidade de ensino e pesquisa.

2. "Introdução aos Estudos Clássicos": ministrada pelo Prof. Dr. Delfim Leão (Universidade de Coimbra), pode-se dizer que os três veios principais da matéria foram: a) ressaltar a importância e a centralidade do mar Mediterrâneo na configuração das civilizações grega e romana, mas também de povos mais antigos como minoicos e micênicos, egípcios, fenícios, etruscos e outros, cujas trocas comerciais e culturais foram constantes, além da transmissão/adaptação de conhecimentos técnicos diversos e de formas de governo como as singulares talassocracias que se alternaram, nesse espaço privilegiado, durante milênios; b) ressaltar a figura de Homero como educador da Grécia, com amplo destaque ao mito/personagem de Odisseu, seja por meio de suas habilidades, astúcia e inteligência (o Odisseu polymetis), seja através do muito que ele sofreu e aprendeu na condição de viajante solitário (o Odisseu polytlas); c) enfim, a diferença entre o polites (o cidadão da pólis) e o kosmopolites (o novo "homem do mundo", universalizado), condições humanas, culturais e sócio-políticas que emba- 
saram, respectivamente, a Grécia Clássica e a Grécia Helenística que se expandiu com as conquistas de Alexandre: esta foi, por sua vez, capturada e absorvida pelo feroz conquistador romano.

3. "Origens Orientais da Cultura Clássica": ministrada pelo Prof. Dr. Edrisi Fernandes (UFRN/UnB), a disciplina propiciou importantes reflexões acerca das várias trocas culturais e comerciais dos gregos com os povos do Oriente Próximo (Ásia Menor), durante os diversos períodos históricos de constituição da civilização grega - aproximações que, no período Helenístico, alcançará terras tão longínquas como Índia e Afeganistão. Dentre alguns exemplos, tem-se que o alfabeto foi absorvido dos fenícios e adaptado às necessidades dos gregos; ou que a Guerra de Troia foi encetada porque a cidade-pedágio era um importante entreposto entre Ocidente e Oriente; ou que a partir do séc. VIII a. C. é na Ásia Menor que a Grécia estabelece suas principais colônias, sendo nestas que eclodirá, no séc. VI a. C., a filosofia de um Tales de Mileto; ou o fato de, entre os sécs. VII-VI a. C. (Idade Arcaica) ter havido uma importante "orientalização" das artes e da cultura grega, o que decisivamente vincará o período Clássico subsequente. Em suma, colocando-se acima de teses contraditórias que defendem, de um lado, o "milagre" grego autóctone, e de outro a avassaladora influência oriental, o curso procurou equacionar a via de mão dupla que permeou os amplos contatos entre os muitos povos mediterrâneos.

4. "Judaísmo, Cristianismo e Helenismo": sob a responsabilidade do Prof. Dr. André Chevitarese (UFRJ), a disciplina continua a discussão dos amplos postulados conceituais das duas anteriores, agora de um ponto de vista mais estritamente religioso. Partindo do questionamento do conceito de "Helenismo" (estabelecido no século XIX) e dos vários modos contraditórios da "helenização" dos povos 
mediterrâneos, o curso procurou evidenciar as interinfluências e as múltiplas trocas de valores materiais e simbólicos, crenças e conhecimentos entre gregos e outros povos mediterrâneos. Num segundo momento (ressaltando, historicamente, a adesão da língua grega na redação dos primeiros Evangelhos), procurou-se rastrear, por exemplo, esquemas narrativos greco-romanos (alegóricos) nos novos relatos do Cristianismo, bem como os ricos e variados tipos de representações visuais (amuletos de Salomão; estelas funerárias; retratos de Maria com o Menino Jesus ao colo ou sendo amamentado), os quais evidenciam os contatos recíprocos entre as culturas em apreço. O último exemplo pode ser associado ao esquema mitológico tradicional e universal mãe/filho (Afrodite/Eros; Ísis/Hórus), cuja apropriação pelo Cristianismo do tema do aleitamento/mãe zelosa foi importante para a constituição da identidade de Jesus e da própria Maria.

5. "História da Filosofia Antiga": ministrada pelo Prof. Dr. Gabriele Cornelli (UnB), logo após o caráter mais geral das três anteriores, esta disciplina mais específica procurou trazer à tona as matrizes da filosofia grega antiga, ligando-a indissoluvelmente à pólis. Cornelli, partindo da matriz homérica (Ilíada), mostra a crise do paradigma antigo, uma vez que a virtude arcaica, vincada pela força e pela violência (Aquiles, o herói exemplar, está além ou aquém do homem-cidadão, mas não se confunde com este), é incompatível com a nova "areté políade" instituída pela figura emblemática de Sócrates, acirradamente defendido por Platão. Pois a filosofia deste, ao fazer a crítica da tradição, articula um triplo conjunto de valores: a) valores herdados dos pré-socráticos (por exemplo, a crença órfico-pitagórica na alma imortal e na metempsicose); b) valores políticos/legais constitutivos da própria pólis ("a alma trágica da cidade", conforme Cornelli), cuja fragilidade é denotada na condenação injusta de Sócrates; c) valores do próprio 
teatro, pois este (ao espelhar/interpretar a cidade e, ao mesmo tempo, formar/ensinar os cidadãos) por certo expressou, na tragédia ou na comédia, a alma dilacerada do homem em confronto com a pólis, consigo mesmo e com o Outro.

6. "Literatura Grega": a cargo da Profa. Dra. Sandra Lúcia Rocha $(U n B)$, que fez um interessante recorte temático a partir do repertório quase infinito da produção literária grega: esta alcança bem mais de um milênio, pois abarca desde a produção oral dos aedos e rapsodos (cuja tradição foi compilada nas conhecidas Ilíada e Odisseia, de Homero, pela altura do séc. VIII a. C.) até o fim da Antiguidade, por volta do séc. $V$ de nossa era. Assim, a partir dos temas fundamentais do amor e da morte (que percorrem não apenas a literatura, mas também a filosofia e a antiga mitologia grega), a Professora selecionou textos de várias épocas, de vários autores e de vários gêneros literários para que refletíssemos sobre os males e os bens de Afrodite (e Eros), bem como sobre a "bela morte" (aquela heroica e gloriosa, do guerreiro homérico) e a morte injusta de um Sócrates, por exemplo, cuja condenação foi prejudicial à própria imagem da cidade. Enfim, a monografia final que elaborei para o I Curso de Especialização teve por inspiração a literatura grega, sob a orientação da Profa. Sandra: porém, condizente com meus interesses atuais, pesquisei e elaborei trabalho sobre As Argonáuticas de Apolônio de Rodes (séc. III a. C.), epopeia do período Helenístico que reconta a saga dos Argonautas e faz da figura de Orfeu importante personagem da aventura, com atributos sacro-sacerdotais que ultrapassam o legado pela mitologia tradicional.

7. "Literatura Latina": ministrada pelo Prof. Dr. José Luís Lopes Brandão (Universidade de Coimbra), a disciplina também fez um recorte interessante da extensa literatura latina: em primeiro lugar es- 
tudou-se conceitualmente a forma literária do "epigrama", de matriz grega mas perfeitamente adaptado a Roma, e trabalhou-se bastante com o epigrama de Marcial (poeta nascido em terras de Espanha e emigrado na Cidade Eterna), cuja concisão e economia de meios foram eficazes para a crítica que ele fez ao cotidiano romano, denunciando os vícios de magnitude variada (mas entranhados em todas as classes sociais), o depauperamento da condição do poeta (um ser à margem) e enfatizando ao mesmo tempo sua relação de amor e ódio com a cidade. Numa segunda etapa, discutiram-se problemas conceituais dos gêneros Biografia e História (que se misturam, na Antiguidade), e privilegiou-se a obra máxima de Suetônio, Vidas dos doze Césares, a partir da qual o Professor assinalou, através da análise, as especificidades da biografia na literatura de Roma.

8. "História romana": sob a responsabilidade da Profa. Dra. Renata Garraffoni (UFPR), a disciplina frisou, desde os primeiros momentos, uma visão renovada da História antiga, seja reavaliando o cotidiano dos gladiadores ou dos soldados do Exército, por exemplo; seja mapeando as relações e correlações de comércio, abastecimento e transporte que se fazia entre Roma e as províncias (e/ou destas entre si); seja decifrando as milhares de inscrições anônimas (de conotação sexual ou de simples troca de informações) dos muros de Pompeia e Herculano; seja documentando a indústria de uma província como a Bética (a moderna Andaluzia, sul da Espanha), cujos produtos (o excelente azeite, a cerâmica, o peixe salgado) eram consumidos em todo o Império. Assim, recusando paradigmas e conceitos prontos, revisando teorias e procedimentos, privilegiando novos sujeitos históricos (pessoas comuns, e não mais imperadores e generais poderosos), a nova História se vale de sugestiva documentação (literária, epigráfica, ico- 
nográfica, arqueológica), num estimulante exercício de inter e multidisciplinaridade.

9. "História Grega": ministrada pelo Prof. Dr. Fábio V. Cerqueira (UFPel), esta disciplina ampara-se sob os mesmos pressupostos conceituais e metodológicos que embasaram o curso anterior. Destarte, estudando principalmente a rica cerâmica grega que nos foi legada, o Professor estabeleceu duas frentes de trabalho: a) primeiro, indagou-se como essa rica iconografia permite repensar as condições de vida, de trabalho e de atividade intelectual e artística da mulher-cidadã; b) depois, como a cerâmica grega, em seus vários estágios, nos leva a refletir sobre os diversos modos pelos quais o homem grego exercia sua sexualidade. Além das relações de gênero (masculino e feminino), o ponto de vista do curso privilegiou também as relações e correlações de mulheres entre si e de homens entre si, abrindo em leque argumentos sobre a faixa etária, a classe social e, notadamente no caso dos homens, sobre homossexualidade, heterossexualidade e papéis masculinos, tanto em conexão uns com os outros, quanto em relação à sociedade como um todo.

10. "Arqueologia e Estudos Clássicos": ministrada pelo Prof. Dr. Pedro Paulo Funari (UNICAMP), a disciplina foi de importância crucial para a compreensão dos estudos atuais de História, conforme as linhas adotadas nas duas abordagens imediatamente acima. Sobre a Arqueologia em particular, aprendemos com o Professor que foi em função dos Estudos Clássicos (firmados entre os sécs. XVIII/XIX) que esta se constituiu no séc. XIX (seus antecedentes são esparsas escavações renascentistas, nos sécs. XV-XVI, e a descoberta de Pompeia em 1748). Se foi mera auxiliar da Literatura, da Filologia e da História oficial, a princípio (preocupadas com os grandes achados e descobertas 
de objetos de valor estético incontestável), hoje a Arqueologia é ciência autônoma e suas preocupações, fins e métodos mudaram bastante desde o século XIX, pois a valorização de objetos comuns e cotidianos (ânforas e outros objetos de cerâmica, inscrições, pinturas parietais, moedas, ruínas de cidades etc.) passa a revelar aspectos antes insuspeitados dos hábitos cotidianos, dos modos de vida, das relações de gênero e da cultura material das várias classes sociais do passado. 0 caso de Pompeia é exemplar: as mais de 10.000 inscrições (epigráficas e iconográficas) descobertas na cidade registram, feito um coletivo jornal comunitário, detalhes sobre o cursus honorum desta ou daquela personagem citadina, sobre lutas de gladiadores, sobre conquistas sexuais, sobre brigas e xingamentos entre desafetos etc.

11. "Metodologia da Pesquisa em Estudos Clássicos": a cargo do Prof. Dr. Silvio Marino (USP/UNICAMP), esta disciplina, conforme já frisado, propiciou aos alunos, além das avaliações de praxe, o desenvolvimento do projeto de pesquisa para a elaboração do Trabalho Final. Tendo como guia os modos pelos quais a filosofia de Platão foi lida/interpretada em dois momentos cruciais da história recente alemã (entre as duas grandes guerras), inclusive de maneira deturpada, o Professor chamou nossa atenção para alguns aspectos importantes da pesquisa em Estudos Clássicos: a relação pesquisador/objeto de pesquisa; o fato de esta ser "uma ponte" que liga nosso presente ao passado (e/ou ao futuro); o fato de que a nossa "reconstrução" (ou interpretação) do passado não é diretamente o passado em sua totalidade, mas uma leitura interpretativa dele, em alguns de seus aspectos (literatura, filosofia, arte, arqueologia, costumes, moral sexual...).

12. "Literatura grega e cinema": ministrada pela Profa. Dra. Maria Cecília de Miranda N. Coelho (UFMG), a matéria fez uma aproxima- 
ção instigante entre uma das mais soberbas formas da arte clássica grega (a tragédia de Ésquilo, Sófocles e Eurípedes) e o cinema, este nosso contemporâneo que também pode, a seu modo vincado pela indústria cultural e pela comunicação de massa, ser um produto eficiente em termos éticos e estéticos. Pois muitas são as formas e as pretensões (éticas e/ou estéticas) do cinema, como muitas foram (e são) as formas do teatro. No caso, trata-se da adaptação das tragédias gregas por renomados ou desconhecidos cineastas mundiais (um Pasolini, um Cacoyannis, um Cocteau...), o que nos possibilitou assistir (ou reassistir) aos filmes com um novo olhar. Assim, depois de discutir, na vídeo-aula, a questão da ira, da vingança e da justiça tal qual aparecem problematizadas na personagem Electra (o mito foi tematizado, como se sabe, por Ésquilo, Sófocles e Eurípides), a ênfase do curso recaiu sobre o filme As troianas (1971), do grego Michael Cacoyannis (1922-2010), adaptado da tragédia de Eurípides. Além deste e de outros filmes, e com o apoio de textos diversos, foi-nos possível refletir sobre as maneiras diversas por que o cinema (ou o teatro, no caso brasileiro) tem adaptado o rico acervo da tradição clássica, às vezes dotando-o de perspectiva crítica que reflete e problematiza nossa própria época de dissolução e liquefação. Ademais, o apreço da disciplina por algumas mulheres emblemáticas do universo grego (Electra, Antígona, Hécuba) já nos leva a refletir sobre a condição ainda precária da muIher no mundo contemporâneo.

13. "Filosofia e Literatura: Recepção da Antiguidade na Literatura Contemporânea": ministrada pelo Prof. Dr. Gilmário Guerreiro da Costa (UCB/UnB), esta instigante disciplina interessou-me em especial, seja pelo arsenal crítico-teórico (quando se refletiu sobre o conceito atemporal de "trágico", ou sobre os conceitos modernos de "fragmentação", "recepção", "alegoria", "perda da aura” etc.), seja pela eleição 
de um escritor brasileiro que me é particularmente caro: João Guimarães Rosa (1908-1967). Assim, para além de generalizações/comparações extenuantes e infrutíferas entre Filosofia e Literatura, centrou-se o foco na maneira plural e personalíssima por que a obra rosiana (em particular seu romance Grande sertão: veredas, 1956) recepciona (e redimensiona) o legado grego, com este intertextualizando em várias camadas: de Homero aproxima-se a caracterização do herói-jagunço (cujo vigor físico e cuja excelência ecoam os heróis da llíada e da Odisseia), além de certa similaridade entre os espaços (o mar em Homero; o sertão em Rosa) pejados de poeticidade e beleza, mas cheios de riscos e sofrimentos para a travessia (apesar do conhecimento que esta efetivamente traz) e classificados como desconhecidos, mágicos e até demoníacos. Da tragédia grega, além da tragicidade inerente à condição humana e ao amor dilacerado (trágico e platônico) que Riobaldo sustenta por Diadorim, o Professor assinalou a cena do julgamento de Zé Bebelo, quando se constitui no sertão um tribunal nos moldes do que se dá nas Eumênides de Ésquilo ou na Apologia de Sócrates de Platão. Em relação a outros temas filosóficos, acrescente-se que os vários tipos de amor vividos por Riobaldo aproximam-se bastante da visão dos estágios do Amor (e da Beleza, do Bem e da Verdade) no Banquete de Platão, cujo exercício da dúvida socrática e a explanação da teoria da reminiscência gozam de um apreço considerável por parte de nosso jagunço-narrador. Pois este, lançando mão de uma linguagem fragmentada e fragmentária (através de aforismos, recuos e ziguezagues narrativos), que encena paradoxos e desencontros, quebra os limites entre prosa e poesia e se vale de uma prosa poética cônscia da concretude da linguagem, procede a uma tentativa de compreender o passado e evitar sua dispersão e esquecimento. Porém, tal escrita fragmentária renuncia a uma visão da totalidade e escancara, trágica e contraditoriamente, a perda, o fracasso e a incurável ferida ontológica 
de Riobaldo. Enfim, em concordância com o Professor, acrescento dois outros elementos que complementam o diálogo produtivo de Rosa com a tradição grega antiga: a travessia do sertão também pode ser comparada à viagem inaugural dos Argonautas, tal qual narrada por Apolônio de Rodes: minha ênfase, claro, é na figura de Orfeu, e menos na de Jasão, porque o bardo Riobaldo constitui um muito peculiar Orfeu sertanejo. Em texto de 2007, a partir dos conceitos "mitopoesia" e "cosmopoesia", aproximo Corpo de baile (1956) do topos milenar (e pitagórico) da "máquina do mundo", centrada na Terra e misteriosamente a nos emitir "O recado do morro", segundo a cosmologia antiga abraçada por Rosa no ciclo de novelas.

14. "Teatro Antigo": sob a responsabilidade do Prof. Dr. Marcus Mota (UnB), o curso estudou em profundidade o teatro grego antigo (notadamente a tragédia), ressaltando a disparidade entre os poucos textos teatrais que nos chegaram e a abundante realidade cênica grega, pois sabe-se que milhares de peças eram então encenadas, tanto em festivais dramático-religiosos atenienses, quanto em eventos similares em outras cidades da Hélade, uma vez que o teatro (como a filosofia, a política, a sátira, o epigrama) se insere profundamente na intrincada vida cotidiana da pólis - aspectos que já evidenciam como era diferente a recepção teatral entre os antigos. Por outro lado, se hoje é quase impossível reconstituir tal realidade dramatúrgica na íntegra, inclusive porque há poucas rubricas e indicações cênicas na maioria dos textos, ainda assim se dá muita atenção aos problemas da performance teatral (e, neste particular, os estudos teatrais têm se valido de outras conquistas dos Estudos Clássicos como a iconografia, a epigrafia e a arqueologia), pois a práxis artística performática (com seu conhecimento específico, interartístico e intersemiótico) busca reviver/reavivar as potencialidades espetaculares virtuais desta ou daquela peça. Com isto, 
novas dimensões têm sido dadas principalmente aos problemas materiais de uma encenação, das condições de pré-produção e produção (coregia) até às disposições do edifício teatral, que adensam o já complexo conjunto de signos intersemióticos que é um espetáculo teatral. Depois de tais questões crítico-teóricas e históricas, o curso disponibilizou para nosso estudo o registro em vídeo/filme de várias encenações/ adaptações contemporâneas do teatro grego, sendo a peça escolhida, para análise preliminar e, depois, comparações diversas, a tragédia Os sete contra Tebas, de Ésquilo.

15. "Arte Antiga": ministrada pela Profa. Dra. Vera Pugliese (UnB), pode-se dizer que esta disciplina "amarrou", através do estudo da arte grega (escultura, pintura e arquitetura), todos os caminhos inter e multidisciplinares abertos pelas anteriores matérias do I Curso de Especialização em Estudos Clássicos. Pois a Professora nos ajudou a fazer, por meio de textos seletos, vídeos, filmes e projeções de slides, um périplo bastante instigante que se iniciou nas origens da civilização grega (quando aprendemos os vários períodos da estatuária e da escultura grega), até à contemporaneidade (quando nos deparamos com o uso dialógico que a arte visual, ainda hoje, faz do legado grego - como, aliás, o cinema, a literatura e o teatro). Em tal viagem, houve duas paradas estratégicas, em estações que foram fundamentais para o estabelecimento do cânone clássico da história da arte ocidental (através da escultura mimético-antropocêntrica, principalmente): a Renascença italiana, uma vez que a disciplina autônoma de História da Arte é uma criação desta, sob a batuta de Giorgio Vasari (1511-1574); e a Alemanha do século XVIII, onde se tem uma nova concepção de arte, agora sob a regência do estudioso Joachim Winckelmann (17171768), cuja concepção pressupunha uma História da Arte vincada pela estilística, pela busca de diferenciação entre os estilos do passado me- 
diante as suas caracterizações morfológicas específicas, e pela mudança de paradigma de Roma para a Grécia antiga, muitíssimo enaltecida na literatura, no teatro, na cultura e no pensamento alemão da época. Um nome fundamental nesse momento é o do escultor italiano Antonio Canova (1757-1822), leitor de Winckelmann, e cuja obra dialoga com a tradição clássica (e helenística) grega, tanto na exploração dos temas mitológicos, quanto na valorização da superfície da escultura, sumamente trabalhada em rigoroso acabamento em prol da expressividade, da emotividade e da dramaticidade das figuras humanas, a que se juntam o gestual e o movimento dos corpos belos, envolvidos por um planejamento também rico e expressivo. Veja-se que tais novas concepções (teóricas e práticas, éticas e estéticas) dão-se ao mesmo tempo em que se descobrem as ruínas de Pompeia (1748) e se desenvolvem a Arqueologia e a Filologia, criando-se subsídios para o pleno incremento dos Estudos Clássicos em moldes que adentrariam o século XX. Hoje, quando se quebram tais paradigmas e se fortalecem outros modos conceituais/científicos de abordar tal herança clássica (conforme se procurou enfatizar através do rico conjunto de disciplinas), pode-se especular que foi no território da própria Arte (que subverteu os conceitos estanques de "beleza", "mimese" e "hegemonia" pelo menos desde o final do século XIX, ao lado da Literatura e do Teatro) que teriam brotado os germens desta nova e revolucionária direção dos Estudos Clássicos contemporâneos.

Pelo exposto, talvez se constate que a tônica do I Curso foi a civilização grega, e menos a romana. Se assim foi, de fato, sinto-me recompensado, por gosto e tendência pessoal. Por outro lado, se Roma, a feroz conquistadora, foi subjugada pela excelência da cultura grega (mesmo tendo dado a esta, em vários campos, uma nova dimensão), é natural que o I Curso, em minha opinião, tenha se preocupado mais 
com a matriz cultural de nosso Ocidente, e menos com a filha que lhe fez propagar a herança, acrescendo-a. Seja como for, fiquemos atentos ao seguinte, a fim de que cada um apanhe o seu quinhão e o lance também avante, no momento oportuno:

É projeto da Cátedra UNESCO Archai UnB que todos os textos trabalhados pelos professores nas vídeos-aula do I Curso de Especialização sejam publicados em livros, na coleção "Filosofia e tradição". Até o momento, foram lançados 2 volumes, a saber: Estudos clássicos I: origens do pensamento ocidental (com ensaios de Delfim Leão, Edrisi Fernandes, André Chevitarese e Gabriele Cornelli) ${ }^{379}$, e Estudos clássicos II: história, literatura e arqueologia (com ensaios de Sandra Lúcia Rocha, José Luís Lopes Brandão, Fábio V. Cerqueira, Renata Garraffoni, Pedro Paulo Funari e Silvio Marino ${ }^{380}$. Oxalá surja, para muito breve, o terceiro volume, completando-se assim o oportuno registro em papel, para perene consulta e novas formas de divulgação, do estimulante I Curso de Especialização em Estudos Clássicos da UnB.

E escrevo "estimulante" para adjetivá-lo porque, de fato, ele o foi para todos nós que acompanhamos e concluímos o curso. Porém, dada a impossibilidade de aqui registrar os passos subsequentes de todos os colegas da Especialização, fiquemos com as palavras do colega (e hoje amigo) Juliano Barcelos Alves: bacharel em Filosofia pela UNISINOS, este gaúcho de longos cabelos loiros e olhos azuis (de beleza algo clássica), hoje cursa o Mestrado em Estudos Clássicos na Universidade

379 Este primeiro volume é localizável pelas seguintes referências bibliográficas: CORNELLI, G.; COSTA, G. G. da. (Org.). Estudos clássicos I: origens do pensamento ocidental. Brasília: UNESCO/Cátedra UNESCO Archai UnB; Coimbra: Imprensa da Universidade; São Paulo: Annablume, 2013 (Coleção Filosofia e tradição, I).

380 Este segundo volume é localizável pelas seguintes referências bibliográficas: CORNELLI, G.; COSTA, G. G. da. (Org.). Estudos clássicos II: história, literatura e arqueologia. Brasília: UNESCO/Cátedra UNESCO Archai UnB; Coimbra: Imprensa da Universidade; São Paulo: Annablume, 2013 (Coleção Filosofia e tradição, II). 
de Coimbra, e de lá me escreveu sinceramente, em e-mail datado de 25/02/2014:

Apenas a certeza do alto nível que essa Especialização teve. [...] o segredo do curso esteve na sua formação, o conjunto de disciplinas que tivemos eu sempre achei perfeito. E mesmo agora que estou em Coimbra, em um Mestrado, e onde tenho acesso ao programa das graduações em Estudos Clássicos também, posso dizer que a nossa Especialização deu-nos tudo o que precisávamos para pisar com passos firmes nessa jornada aos EC.

Quanto a mim, além da honra de ter sido convidado a escrever estas páginas, devo dizer que, sob a supervisão do Prof. Dr. Gabriele Cornelli, iniciei junto à Cátedra UNESCO Archai UnB, já no segundo semestre de 2013, um estágio de pós-doutoramento em que desdobro minha pesquisa sobre o mito de Orfeu e o orfismo e os aproximo da filosofia grega antiga, no projeto intitulado "Orfeu entre os filósofos: estudo do mito e do Orfismo no pensamento grego antigo".

E porque qualquer conclusão, aqui, é provisória, almejemos que todos os colegas e professores pioneiros continuemos a partilhar do ensinado e do aprendido em nossas cartilhas, e que novas turmas, no decorrer dos anos, possam delas também haurir proveito e palmiIhar estes e outros caminhos abertos pelo I Curso de Especialização em Estudos Clássicos da UnB.

Araraquara, março de 2014 